\title{
Ethanol adsorption onto metal organic framework: Theory and experiments
}

\author{
Bidyut Baran Saha ${ }^{1,4}$, Ibrahim I. El-Sharkawy ${ }^{2,3,4}$, Takahiko Miyazaki ${ }^{2,4}$ \\ Shigeru Koyama ${ }^{1,2,4}$, Stefan K. Henninger ${ }^{5}$, Annika Herbst ${ }^{6}$, Christoph Janiak ${ }^{6}$ \\ ${ }^{1}$ Interdisciplinary Graduate School of Engineering Sciences, Kyushu University \\ Kasuga-koen 6-1, Kasuga-shi, Fukuoka 816-8580, Japan \\ ${ }^{2}$ Faculty of Engineering Sciences, Kyushu University \\ Kasuga-koen 6-1, Kasuga-shi, Fukuoka 816-8580, Japan \\ ${ }^{3}$ Mechanical Power Engineering Department, Faculty of Engineering \\ Mansoura University, El-Mansoura 35516, Egypt \\ ${ }^{4}$ International Institute for Carbon-Neutral Energy Research (WPI-I2CNER), Kyushu University \\ 744 Motooka, Nishi-ku, Fukuoka 819-0395, Japan \\ ${ }^{5}$ Fraunhofer Institute for Solar Energy Systems (ISE), Dept. Thermally Active Materials and \\ Solar Cooling Heidenhofst, 2-79110 Freiburg, Germany \\ ${ }^{6}$ Institut für Anorganische Chemie und Strukturchemie, University of Düsseldorf \\ Universitätsstr. 1, D-40225 Düsseldorf, Germany \\ *Author to whom correspondence should be addressed, E-mail: \\ saha.baran.bidyut.213@m.kyushu-u.ac.jp
}

\begin{abstract}
:
This paper presents experimental and theoretical investigations of adsorption characteristics of ethanol onto metal organic framework namely MIL-101Cr. Adsorption isotherms and kinetics of the studied pair have been measured gravimetrically using a magnetic suspension adsorption measurement unit and volumetrically employing a Quantachrome Autosorb iQ MP machine. The
\end{abstract}


present experiments have been conducted within relative pressures between 0.1 and 0.9 and adsorption temperatures ranging from 30 to $70{ }^{\circ} \mathrm{C}$, which are suitable for adsorption cooling applications. Adsorption isotherm data exhibit that $1 \mathrm{~kg}$ of MIL-101Cr can adsorb as high as 1.1 $\mathrm{kg}$ of ethanol at adsorption temperature of $30^{\circ} \mathrm{C}$, and the Tóth equation has been used to fit the experimentally measured data. As of the experimentally measured adsorption uptake rate data, the Fickian diffusion model is found to be suitable. These data are essential for designing a new generation of adsorption chiller.

Keywords: adsorption isotherms; adsorption kinetics; ethanol; metal organic framework.

\section{Nomenclature}

A surface area of adsorbent $\left(\mathrm{m}^{2}\right)$

b the affinity constant presented in Eq. $2\left(\mathrm{kPa}^{-1}\right)$

$b_{o} \quad$ the affinity at the reference temperature $\left(\mathrm{kPa}^{-1}\right)$

D diffusivity $\left(\mathrm{m}^{2} \mathrm{~s}^{-1}\right)$

$D_{\text {so }} \quad$ pre-exponential constant $\left(\mathrm{m}^{2} \mathrm{~s}^{-1}\right)$

E adsorption characteristics parameter $\left(\mathrm{kJ} \mathrm{Kg}^{-1}\right)$

$\mathrm{E}_{\mathrm{a}} \quad$ activation energy $\left(\mathrm{kJ} \mathrm{kg}^{-1}\right)$

F fractional uptake (-)

$\mathrm{p} \quad$ equilibrium pressure $(\mathrm{kPa})$

$\mathrm{p}_{\mathrm{S}} \quad$ saturation pressure $(\mathrm{kPa})$

$Q \quad$ isosteric heat of adsorption at zero fractional uptake $\left(\mathrm{kJ} \mathrm{kmol}^{-1}\right)$ 


$$
\begin{array}{ll}
\mathrm{R} & \text { universal gas constant }\left(\mathrm{kJ} \mathrm{kmol}^{-1} \mathrm{~K}^{-1}\right) \\
\mathrm{R}_{\mathrm{g}} & \text { gas constant }\left(\mathrm{kJ} \mathrm{kg}^{-1} \mathrm{~K}^{-1}\right) \\
\mathrm{R}_{\mathrm{p}} & \text { particle radius }(\mathrm{m}) \\
\mathrm{T} & \text { temperature }(\mathrm{K}) \\
T_{o} & \text { reference temperature }(\mathrm{K}) \\
\mathrm{t} & \text { time (s) and parameter in Tóth isotherm (-) } \\
\mathrm{V} & \text { the adsorbent particle volume }\left(\mathrm{m}^{3}\right) \\
\mathrm{W}^{3} & \text { equilibrium adsorption uptake }\left(\mathrm{kg} \mathrm{kg}^{-1}\right) \\
\mathrm{W} & \text { instantaneous adsorption uptake }\left(\mathrm{kg} \mathrm{kg}^{-1}\right) \\
\mathrm{W}_{\mathrm{in}} & \text { initial uptake (kg kg } \left.{ }^{-1}\right) \\
\mathrm{W}_{\mathrm{s}} & \text { saturated adsorption capacity }\left(\mathrm{kg} \mathrm{kg}^{-1}\right) \\
\mathrm{W}_{\mathrm{o}} & \text { reference adsorption capacity }\left(\mathrm{kg} \mathrm{kg}^{-1}\right) \\
\varphi & \text { constant temperature of Eq. }(3)
\end{array}
$$

\section{Introduction}

Metal-organic frameworks (MOFs) are materials in which metal-to-organic ligand interactions yield porous coordination networks. It is proven that the MOFs have higher surface area than activated carbons and zeolites. They are widely used in methane and hydrogen storage, gas separation and catalysis [1-9]. Moreover, extensive research efforts have been conducted recently to investigate the possible use of the MOFs in adsorption cooling applications. Following are some representative examples. Henninger et al. [10] tested the cycle stability of sorption materials and composites for possible use in heat pumps and adsorption cooling. The authors tested common materials such as silica gels and zeolites and other developed materials 
like aluminophosphates (AlPO), silica aluminophosphates (SAPO) and metal organic frameworks. The studied materials have been analyzed under continuous thermal cycling in a water vapor atmosphere. Jeremias et al. [11] discussed the feasibility of using the metal-organic frameworks $\mathrm{UiO}-66(\mathrm{Zr}), \mathrm{UiO}-67(\mathrm{Zr}), \quad \mathrm{H}_{2} \mathrm{~N}-\mathrm{UiO}-66(\mathrm{Zr})$ and $\mathrm{H}_{2} \mathrm{~N}-\mathrm{MIL}-125(\mathrm{Ti})$ in heat transformation. Adsorption isotherms of water onto the studied types of MOFs have been presented and analyzed. Water sorption onto functionalized MIL-101Cr has also been investigated for possible use in adsorption chillers [12]. Adsorption characteristics of water into two types of MOFs has been experimentally investigated and compared with that of silica gel/water pair [13]. Aristov [14] reviewed several classes of materials potentially promising for adsorption heat transformation applications. These materials include metalaluminophosphates (AlPOs, SAPOs, MeAPOs), selected types of metal-organic frameworks, ordered porous solids, porous carbons and various composites (SWSs, AlPO-Al foil). Other studies on adsorbent/refrigerant pairs for cooling applications could be found elsewhere [15-30] . However, there is no precise analysis on the adsorption isotherm and kinetics of ethanol on to MOFs.

From the above perspectives, this study presents an experimental investigation on adsorption characteristics of $\mathrm{MIL}-101 \mathrm{Cr}+$ ethanol pair for adsorption cooling applications. Adsorption isotherms and kinetics of the studied pair have been measured within adsorption temperatures ranging from 30 to $70{ }^{\circ} \mathrm{C}$ and relative pressures between 0.1 and 0.9 . Tóth equation is used to express the adsorption isotherm data whilst Fickian diffusion model is found to be suitable to present the adsorption kinetics.

\section{Materials}

\subsection{Structure of $M I L-101 C r$}


The compound MIL-101Cr, introduced by the group of Férey [31] as Material du Institut Lavoisier No. 101 is by now one of the best known and most cited MOFs. A pore volume of $V_{\text {Pore }}=2.0 \mathrm{~cm}^{3} \mathrm{~g}^{-1}$ and very high internal surface area of $S_{\mathrm{BET}}=4100 \pm 200 \mathrm{~m}^{2} \mathrm{~g}^{-1}$ have been reported for this mesoporous chromium(III) terephthalate, calculated from $\mathrm{N}_{2}$ adsorption isotherms.

The framework is similar to that of the MZN zeolite topology with an empirical formula $\left[\mathrm{Cr}_{3}(\mathrm{O})(\mathrm{bdc})_{3}(\mathrm{~F}, \mathrm{OH})\left(\mathrm{H}_{2} \mathrm{O}\right)_{2}\right]$. The building blocks are benzene-1,4-dicarboxylate ligands bridging $\mathrm{Cr}_{3} \mathrm{O}$ units thereby forming trinuclear $\left\{\mathrm{Cr} 3(\mu 3-\mathrm{O})\left(\mathrm{O}_{2} \mathrm{C}-\right) 6(\mathrm{~F}, \mathrm{OH})\left(\mathrm{H}_{2} \mathrm{O}\right) 2\right\}$ building units (SBUs) (see Fig. 1a). MIL-101Cr has two terminal water molecules connected to the trinuclear $\left\{\mathrm{Cr}_{3}\left(\mu_{3}-\mathrm{O}\right)\left(\mathrm{O}_{2} \mathrm{C}-\right)_{6}(\mathrm{~F}, \mathrm{OH})\left(\mathrm{H}_{2} \mathrm{O}\right)_{2}\right\}$ building units with their octahedral $\mathrm{Cr}(\mathrm{III})$ ions. The trinculear units are vertices of supertetrahedra (Fig. 1b). The vertex-sharing supertetrahedra (b) then form a three-dimensional network (Fig. 1c) with two types of mesoporous cages. The small cage (Fig. 1d) has an inner diameter $29 \AA$ and only pentagonal windows. The large cage (Fig. 1e) has an inner diameter of $34 \AA$ and both pentagonal and hexagonal windows. The window apertures are $12 \AA$ or $15-16 \AA$, respectively (Fig. 1f). MIL-101Cr crystal was obtained with octahedral crystal morphology in the range of $0.1 \mu \mathrm{m}$ to $1 \mu \mathrm{m}$. The SEM picture of MIL-101Cr is shown in Fig. 2.

\subsection{Surface and pore analysis}

Surface and pore analysis by nitrogen adsorption were performed on a Quantachrome Nova 3000. The nitrogen adsorption at $77.4 \mathrm{~K}$ shows the previously reported shape with a steep increase within low relative pressure followed by a characteristic second step at a relative pressure of approximately $0.19 \mathrm{p} / \mathrm{p}_{0}$ (see Fig. 3). Surface area has been calculated to be 3318 
$\mathrm{m}^{2} \mathrm{~g}^{-1}$ using the multi-point BET approach on the adsorption path within the relative pressure range of $0.04-0.2 \mathrm{p} / \mathrm{p}_{0}$. This value is significantly below the reported surface area of up to 4230 $\mathrm{m}^{2} \mathrm{~g}^{-1}$ [32]. This is due to the purification step. As reported by Hong et al. [32], the purification has a major influence on the surface area. In the present work, BET areas of $2800 \mathrm{~m}^{2} \mathrm{~g}^{-1}$ up to $4230 \mathrm{~m}^{2} \mathrm{~g}^{-1}$ were reported on the same batch, with different purification means. The reported purification technique employed hot ethanol/water and aqueous ammonium fluoride $\left(\mathrm{NH}_{4} \mathrm{~F}\right)$ treatment, whereas we only washed the MOF sample within DMF and ethanol at room temperature without $\mathrm{NH}_{4} \mathrm{~F}$ treatment. However, the total pore volume, measured at a relative pressure $\mathrm{p} / \mathrm{p}_{0}=0.98$ was determined to $2.02 \mathrm{~cm}^{3} \mathrm{~g}^{-1}$ which is in good agreement to the reported volume of up to $2.15 \mathrm{~cm}^{3} \mathrm{~g}^{-1}$. Pore size distribution calculation by NLDFT using a cylindrical pore model reveals two pores at about $10 \AA$ and $16 \AA$, which are slightly lower than those estimated from the crystal structure given above [32].

\section{Experimental apparatus and procedure}

Adsorption isotherms and kinetics of the studied pair has been measured gravimetrically using a magnetic suspension adsorption measurement unit of type MSB-VG-S2. Figure 4 shows a pictorial view of the magnetic suspension balance section which comprises; (i) balance to measure the weight of sample using a suspending system, (ii) magnetic coupling section which is equipped with the permanent magnet, (iii) circulation oil jacket to perform stable temperature control during the measurements, (iv) isothermal circulation oil bath, (v) sample cell, and (vi) sheathed heater to heat the sample cell. Both the magnetic coupling section and sample cell is isolated using thermal insulation. The repeatability of the weight measurements is $\pm 30 \mu \mathrm{g}$ with a relative error of $\pm 0.002 \%$ of the reading. Three types of pressure gauges namely; (i) $3500 \mathrm{kPa}$, 
Keller PAA-35XHTT-35, (ii) $133.3 \mathrm{kPa}$, MKS 628B13TBE1B, and (iii) $13.3 \mathrm{kPa}$, MKS 628B12TBE1B with an accuracy of $0.15-0.25 \% \mathrm{FS}$ are used for the pressure measurements. A platinum temperature element (Pt 100U) is used to control and measure the temperature of the sample section. For each isotherm, the adsorption temperature is kept constant whilst evaporator temperature is increased stepwise. Mass of dry adsorbent sample used in the present measurements is $44.8 \mathrm{mg}$. A detailed description of the experimental procedure has been presented by El-Sharkawy et al. [23].

The volumetric ethanol adsorption isotherm is measured with a Quantachrome Autosorb iQ MP instrument at a temperature of $20^{\circ} \mathrm{C}$.

\section{Results and discussion}

\subsection{Adsorption isotherms}

Figures 5(a)-5(e) shows the gravimetric adsorption isotherms of MIL-101Cr/ethanol pair for adsorption temperatures ranging from 30 to $70{ }^{\circ} \mathrm{C}$ and relative pressures between 0.1 and 0.9 . For each adsorption isotherm, the adsorbent sample temperature is kept constant whilst the evaporator temperature increases stepwise until the relative pressure reaches above 0.9. It can be seen from Figures 5(a)-5(e) that, the adsorption capacity of MIL-101Cr/ethanol pair is as high as $1.1 \mathrm{~kg} \mathrm{~kg}^{-1}$ at adsorption temperature of $30{ }^{\circ} \mathrm{C}$. It can be observed that, the adsorption capacity increases with the increase of relative pressure until it reaches 0.3 or 0.4 . After that the increase in adsorption capacity is only marginal. Tóth equation (Eq. 1) is used to fit the adsorption isotherms of the studied pair [33].

$$
W=W_{s} \frac{b p}{\left[1+(b p)^{t}\right]^{\frac{1}{t}}}
$$


where;

$$
\begin{aligned}
& b=b_{o} \exp \left(\frac{Q}{R T}-\frac{Q}{R T_{o}}\right) \\
& W_{s}=W_{o} \exp \left(\varphi\left(1-\frac{T}{T_{o}}\right)\right)
\end{aligned}
$$

Where $W$ is the adsorption equilibrium uptake, $W_{s}$ is the saturated adsorption capacity whilst $W_{o}$ is the reference adsorption capacity. In the present study, the reference temperature is considered as $303 \mathrm{~K}$. The parameters $b$ is the affinity constant and $b_{o}$ represents the affinity at the reference temperature. The term $\varphi$ is a constant temperature, and $Q$ is the measure of isosteric heat of adsorption at zero fractional uptake. Figure 6 shows the measured adsorption isotherms and the fitting with Tóth equation. The numerical values of the Tóth parameters are enumerated in Table 1. As reported earlier, MIL-101 shows high uptakes of organic vapors e.g. benzene or methanol $[32,34]$. The volumetric adsorption isotherm for ethanol onto MIL- $101 \mathrm{Cr}$ at $20{ }^{\circ} \mathrm{C}$ is presented in Fig. 7. The very high ethanol uptake of already $\sim 0.2 \mathrm{~kg} \mathrm{~kg}^{-1}$ at low relative pressure of 0.05 $\mathrm{p} / \mathrm{p}_{0}$ can be attributed to the co-ordinatively unsaturated metal sites (CUS). As reported by Hong et al. [32], the original present terminal water molecules at the chromium (III) cluster can be removed by heating up to $150{ }^{\circ} \mathrm{C}$ under evacuation. Thus, first strong adsorption of ethanol molecules is likely to appear at the CUS. An almost linear uptake can be observed for relative pressure up to approximately $0.35 \mathrm{p} / \mathrm{p}_{0}$, corresponding to a continuous filling of the smaller cages with diameter of $29 \AA$ (see Fig. 1d) and an additional loading of up to $\sim 0.95 \mathrm{~kg} \mathrm{~kg}^{-1}$. Following a relative pressure of $0.35 \mathrm{p} / \mathrm{p}_{0}$, which may be attributed to the filling of the larger cages (see Fig. 1e), the loading finally approaching a plateau with a total uptake of $1.1 \mathrm{~kg} \mathrm{~kg}^{-1}$. 


\subsection{Adsorption kinetics}

Figures 8 and 9 show the temporal profiles of adsorption uptake and pressure of the studied pair at adsorption temperatures of 30 and $70{ }^{\circ} \mathrm{C}$, respectively. It is visible that, adsorption kinetics of the studied pair is relatively faster at the early stages of adsorption processes. To estimate the adsorption uptake rate of spherical shape adsorbent the following differential equation [35] can be used,

$$
\frac{\partial w}{\partial t}=\frac{1}{r^{2}} \frac{\partial}{\partial r}\left(r^{2} D \frac{\partial w}{\partial r}\right)
$$

Solution of equation (4) is given by Eq. (5) below [36] ;

$$
F=\frac{w-w_{i n}}{W-w_{i n}}=1-\frac{6}{\pi^{2}} \sum_{n=1}^{\infty} \frac{1}{n^{2}} \exp \left(-\frac{n^{2} \pi^{2} D t}{R_{p}^{2}}\right)
$$

During the initial phase of adsorption, the diffusion time constant $\left(D / R_{p}{ }^{2}\right)$ can be assessed using Eq. (6) below [35];

$$
F \approx \frac{2 A}{V}\left(\frac{D t}{\pi}\right)^{\frac{1}{2}}
$$

In Eq. (6), the right hand side presents the fractional uptake, $A$ is the surface area of adsorbent and $V$ is the adsorbent particle volume. Eq. (6) can be simplified as given below;

$$
F \approx \frac{6}{\sqrt{\pi}} \sqrt{\frac{D}{R_{p}^{2}} t}
$$

Using Eq. (7), the diffusion time constant $\left(D / R_{p}{ }^{2}\right)$ is evaluated for each adsorption step. It is found that, the estimated diffusion time constant of MIL-101Cr/ethanol pair provides underestimation of adsorption uptake for all adsorption isotherms. Therefore, a diffusion time 
constant correction factor of 1.2 is used at all adsorption isotherms. Fractional uptake plots of experimental versus Fickian diffusion model for certain adsorption steps are shown in Fig. 10. One can see from Fig. 10 that, the maximum percentage of deviation is about $\pm 13 \%$.

The average values of the diffusion time constant of the first three steps are estimated (see Table 2) and the plot of $\ln \left(D / R_{p}{ }^{2}\right)$ versus $(1 / T)$ is presented in Fig. 11. Numerical values of the activation energy $E_{a}$ and the pre-exponent constant $\left(D_{s o} / R_{p}{ }^{2}\right)$ are predicted using the Arrhenius equation given below;

$$
D=D_{s o} \exp \left(\frac{-E_{a}}{R_{g} T}\right)
$$

The diffusion time constant varies with $(1 / T)$ according to the following expression;

$$
\ln \left(\frac{D}{R_{p}^{2}}\right)=\ln \left(\frac{D_{s o}}{R_{p}^{2}}\right)-\left(\frac{E_{a}}{R_{g}}\right)\left(\frac{1}{T}\right)
$$

Experimental results show that the numerical values of $E_{a}$ and $\left(D_{s o} / R_{p}{ }^{2}\right)$ are $770 \mathrm{~kJ} \mathrm{~kg}^{-1}$ and 404 $\mathrm{s}^{-1}$, respectively. One can notice that the activation energy of MIL-101Cr/ethanol pair is significantly higher than that of other activated carbons/ethanol pairs [23]. It can be noticed that the diffusion time constant of the studied pair has stronger dependency on adsorption temperatures in comparison with that of the carbon based adsorbents + ethanol pairs.

\section{Conclusions}

Adsorption isotherms and kinetics of MIL-101Cr/ethanol pair has been measured gravimetrically using a magnetic suspension adsorption measurement instrument and volumetrically employing a Quantachrome Autosorb iQ MP machine. Experimental results show that the assorted 
adsorbent, MIL-101Cr, can adsorb up to $1.1 \mathrm{~kg}$ of ethanol per $\mathrm{kg}$ of dry adsorbent. The Tóth adsorption isotherm model is used to fit the adsorption equilibrium uptake of the studied pair whilst the Fickian diffusion model is used to represent adsorption kinetics. It is found that the diffusion time constant of the studied pair strongly depends on adsorption temperatures. Experimental results show that the studied pair would be a promising candidate for developing high performance cooling device.

\section{Acknowledgements}

This work was financially supported by Japan Science and Technology Agency (JST), Core Research for Evolutional Science and Technology (CREST). 


\section{References}

[1] Murray LJ, Dinca M, Long JR. Hydrogen storage in metal-organic frameworks. Chem Soc Rev. 2009;38(5):1294-314.

[2] Saha D, Wei Z, Deng S. Equilibrium, kinetics and enthalpy of hydrogen adsorption in MOF177. International Journal of Hydrogen Energy. 2008;33(24):7479-88.

[3] Sanz R, Martinez F, Orcajo G, Wojtas L, Briones D. Synthesis of a honeycomb-like Cubased metal-organic framework and its carbon dioxide adsorption behaviour. Dalton Trans. 2013;42(7):2392-8.

[4] Munusamy K, Sethia G, Patil DV, Somayajulu Rallapalli PB, Somani RS, Bajaj HC. Sorption of carbon dioxide, methane, nitrogen and carbon monoxide on MIL-101(Cr): Volumetric measurements and dynamic adsorption studies. Chemical Engineering Journal. 2012;195196:359-68.

[5] Li J-R, Ma Y, McCarthy MC, Sculley J, Yu J, Jeong H-K, et al. Carbon dioxide capturerelated gas adsorption and separation in metal-organic frameworks. Coordination Chemistry Reviews. 2011;255(15-16):1791-823.

[6] Henschel A, Gedrich K, Kraehnert R, Kaskel S. Catalytic properties of MIL-101. Chem Commun (Camb). 2008(35):4192-4.

[7] Li Y, Yang RT. Gas adsorption and storage in metal-organic framework MOF-177. Langmuir. 2007;23(26):12937-44.

[8] Llewellyn PL, Bourrelly S, Serre C, Vimont A, Daturi M, Hamon L, et al. High uptakes of $\mathrm{CO} 2$ and $\mathrm{CH} 4$ in mesoporous metal-organic frameworks MIL-100 and MIL-101. Langmuir. 2008;24(14):7245-50.

[9] Lin RB, Chen D, Lin YY, Zhang JP, Chen XM. A zeolite-like zinc triazolate framework with high gas adsorption and separation performance. Inorg Chem. 2012;51(18):9950-5.

[10] Henninger SK, Munz G, Ratzsch KF, Schossig P. Cycle stability of sorption materials and composites for the use in heat pumps and cooling machines. Renewable Energy. 2011;36(11):3043-9.

[11] Jeremias F, Lozan V, Henninger SK, Janiak C. Programming MOFs for water sorption: amino-functionalized MIL-125 and UiO-66 for heat transformation and heat storage applications. Dalton Trans. 2013;42(45):15967-73. 
[12] Khutia A, Rammelberg HU, Schmidt T, Henninger S, Janiak C. Water Sorption Cycle Measurements on Functionalized MIL-101Cr for Heat Transformation Application. Chemistry of Materials. 2013;25(5):790-8.

[13] Rezk A, Al-Dadah R, Mahmoud S, Elsayed A. Characterisation of metal organic frameworks for adsorption cooling. International Journal of Heat and Mass Transfer. 2012;55(25-26):7366-74.

[14] Aristov YI. Challenging offers of material science for adsorption heat transformation: A review. Applied Thermal Engineering. 2013;50(2):1610-8.

[15] Henninger SK, Habib HA, Janiak C. MOFs as adsorbents for low temperature heating and cooling applications. Journal of the American Chemical Society. 2009;131(8):2776-7.

[16] Henninger SK, Jeremias F, Kummer H, Schossig P, Henning H-M. Novel Sorption Materials for Solar Heating and Cooling. Energy Procedia. 2012;30:279-88.

[17] Henninger SK, Schmidt FP, Henning HM. Water adsorption characteristics of novel materials for heat transformation applications. Applied Thermal Engineering. 2010;30(13):1692702.

[18] Wickenheisser M, Jeremias F, Henninger SK, Janiak C. Grafting of hydrophilic ethylene glycols or ethylenediamine on coordinatively unsaturated metal sites in MIL-100(Cr) for improved water adsorption characteristics. Inorganica Chimica Acta. 2013;407:145-52.

[19] Rezk A, Al-Dadah R, Mahmoud S, Elsayed A. Investigation of Ethanol/metal organic frameworks for low temperature adsorption cooling applications. Applied Energy. 2013;112:1025-31.

[20] Aristov YI, Restuccia G, Cacciola G, Parmon VN. A family of new working materials for solid sorption air conditioning systems. Applied Thermal Engineering. 2002;22(2):191-204.

[21] Follin S, Goetz V, Guillot A. Influence of Microporous Characteristics of Activated Carbons on the Performance of an Adsorption Cycle for Refrigeration. Industrial \& Engineering Chemistry Research. 1996;35(8):2632-9.

[22] Saha BB, El-Sharkawy II, Habib K, Koyama S, Srinivasan K. Adsorption of equal mass fraction near an azeotropic mixture of pentafluoroethane and 1,1,1-trifluoroethane on activated carbon. Journal of Chemical and Engineering Data. 2008;53(8):1872-6. 
[23] El-Sharkawy II, Uddin K, Miyazaki T, Saha BB, Koyama S, Miyawaki J, et al. Adsorption of ethanol onto parent and surface treated activated carbon powders. International Journal of Heat and Mass Transfer. 2014;73:445-55.

[24] Gordeeva LG, Aristov YI. Composite sorbent of methanol "LiCl in mesoporous silica gel" for adsorption cooling: Dynamic optimization. Energy. 2011;36(2):1273-9.

[25] El-Sharkawy II, Hassan M, Saha BB, Koyama S, Nasr MM. Study on adsorption of methanol onto carbon based adsorbents. International Journal of Refrigeration. 2009;32(7):157986.

[26] Saha BB, Jribi S, Koyama S, El-Sharkawy II. Carbon Dioxide Adsorption Isotherms on Activated Carbons. Journal of Chemical \& Engineering Data. 2011;56(5):1974-81.

[27] Cui Q, Tao G, Chen H, Guo X, Yao H. Environmentally benign working pairs for adsorption refrigeration. Energy. 2005;30(2-4):261-71.

[28] Gordeeva L, Aristov Y. Novel sorbents of ethanol "salt confined to porous matrix" for adsorptive cooling. Energy. 2010;35(6):2703-8.

[29] Chakraborty A, Leong KC, Thu K, Saha BB, Ng KC. Theoretical insight of adsorption cooling. Applied Physics Letters. 2011;98(22), 221910.

[30] Sun B, Chakraborty A. Thermodynamic formalism of water uptakes on solid porous adsorbents for adsorption cooling applications. Applied Physics Letters. 2014;104(20), 201901.

[31] Férey C, Mellot-Draznieks C, Serre C, Millange F, Dutour J, Surblé S, et al. Chemistry: A chromium terephthalate-based solid with unusually large pore volumes and surface area. Science. 2005;309(5743):2040-2.

[32] Hong DY, Hwang YK, Serre C, Férey G, Chang JS. Porous chromium terephthalate MIL101 with coordinatively unsaturated sites: Surface functionalization, encapsulation, sorption and catalysis. Advanced Functional Materials. 2009;19(10):1537-52.

[33] Do DD. Adsorption Analysis: Equilibria and Kinetics: Imperial College Press, 1998.

[34] Jeremias F, Frohlich D, Janiak C, Henninger SK. Water and methanol adsorption on MOFs for cycling heat transformation processes. New Journal of Chemistry. 2014;38(5):1846-52.

[35] Ruthven DM. Principles of Adsorption and Adsorption Processes. New York: Wiley, 1984.

[36] Crank J. Mathematics of Diffusion. London: Oxford University Press, 1956. 


\section{List of Tables}

Table 1: Parameters of Tóth isotherms model.

Table 2: Numerical values of diffusion time constant of MIL-101Cr/ethanol pair. 


\section{Table 1}

Parameters of Tóth isotherms model.

Tóth parameters covering adsorption temperature from 30 to $70{ }^{\circ} \mathrm{C}$

\begin{tabular}{cccccc}
\hline Temperature $\left[{ }^{\circ} \mathrm{C}\right]$ & $W_{o}$ & $b_{o}$ & $\mathrm{t}$ & $\frac{Q}{R T_{o}}$ & $\varphi$ \\
\hline $30 \sim 70$ & 1.150 & 0.342 & 2.193 & 17.845 & 0.358 \\
\hline
\end{tabular}




\section{Table 2}

Numerical values of diffusion time constant of MIL-101Cr/ethanol pair.

\begin{tabular}{|c|c|c|}
\hline $\begin{array}{l}\mathrm{T}_{\mathrm{ads}}, \\
{\left[{ }^{\circ} \mathrm{C}\right]}\end{array}$ & $\begin{array}{c}\text { Equilibrium Pressure, } \\
\qquad[\mathrm{kPa}]\end{array}$ & $\begin{array}{c}\mathrm{D} / \mathrm{R}_{\mathrm{p}}^{2} \\
{\left[\mathrm{~s}^{-1}\right]}\end{array}$ \\
\hline \multirow[t]{3}{*}{30.0} & 1.19 & $4.50 \times 10^{-4}$ \\
\hline & 1.78 & $3.61 \times 10^{-4}$ \\
\hline & 2.38 & $1.08 \times 10^{-4}$ \\
\hline \multirow[t]{3}{*}{40.1} & 1.89 & $7.76 \times 10^{-4}$ \\
\hline & 2.89 & $5.17 \times 10^{-4}$ \\
\hline & 4.03 & $1.67 \times 10^{-4}$ \\
\hline \multirow[t]{3}{*}{49.9} & 1.66 & $1.03 \times 10^{-3}$ \\
\hline & 3.41 & $7.58 \times 10^{-4}$ \\
\hline & 5.03 & $6.52 \times 10^{-4}$ \\
\hline \multirow[t]{3}{*}{60.0} & 2.47 & $1.47 \times 10^{-3}$ \\
\hline & 5.30 & $1.13 \times 10^{-3}$ \\
\hline & 8.33 & $8.83 \times 10^{-4}$ \\
\hline \multirow[t]{3}{*}{69.9} & 4.07 & $2.25 \times 10^{-3}$ \\
\hline & 8.94 & $1.35 \times 10^{-3}$ \\
\hline & 12.94 & $1.02 \times 10^{-3}$ \\
\hline
\end{tabular}




\section{List of Figures}

Fig. 1. (a) ligand and metal building blocks in the trinuclear $\left\{\mathrm{Cr}_{3}\left(\mu_{3}-\mathrm{O}\right)\left(\mathrm{O}_{2} \mathrm{C}-\right)_{6}(\mathrm{~F}, \mathrm{OH})\left(\mathrm{H}_{2} \mathrm{O}\right)_{2}\right\}$ building unit; (b) supertetrahedra; (c) mesoporous network; (d) small cage with pentagonal windows; (e) large cage with pentagonal and hexagonal windows; (f) dimensions of pentagonal and hexagonal cage window apertures. Objects in (a) to (f) are not drawn to scale. Graphics have been created from the deposited cif-file for MIL-101Cr (CSD-Refcode OCUNAK).

Fig. 2. The SEM picture of MIL-101Cr.

Fig. 3. Nitrogen adsorption and desorption isotherm.

Fig. 4. Pictorial view of magnetic suspension balance section.

Fig. 5. Gravimetric adsorption isotherms of MIL-101Cr/ethanol pair.

Fig. 6. Adsorption Isotherms using Tóth equation (symbols: experiments; Tóth fitting at individual adsorption temperatures: solid line; Tóth fitting using all temperature range: dashed lines).

Fig. 7. Volumetric sorption isotherm of MIL-101Cr/ethanol pair at $20{ }^{\circ} \mathrm{C}$. The closed and open symbols refer to adsorption and desorption, respectively.

Fig. 8. Plots of adsorption uptake and pressure versus time for MIL-101Cr/ethanol pair at adsorption temperature of $30^{\circ} \mathrm{C}$.

Fig. 9. Plots of adsorption uptake and pressure versus time for MIL-101Cr/ethanol pair at adsorption temperature of $70^{\circ} \mathrm{C}$.

Fig. 10. Plots of adsorption uptake and pressure versus time for MIL-101Cr/ethanol pair at adsorption temperature of $70^{\circ} \mathrm{C}$.

Fig. 11. Arrhenius plot of MIL-101Cr/ethanol pair. 

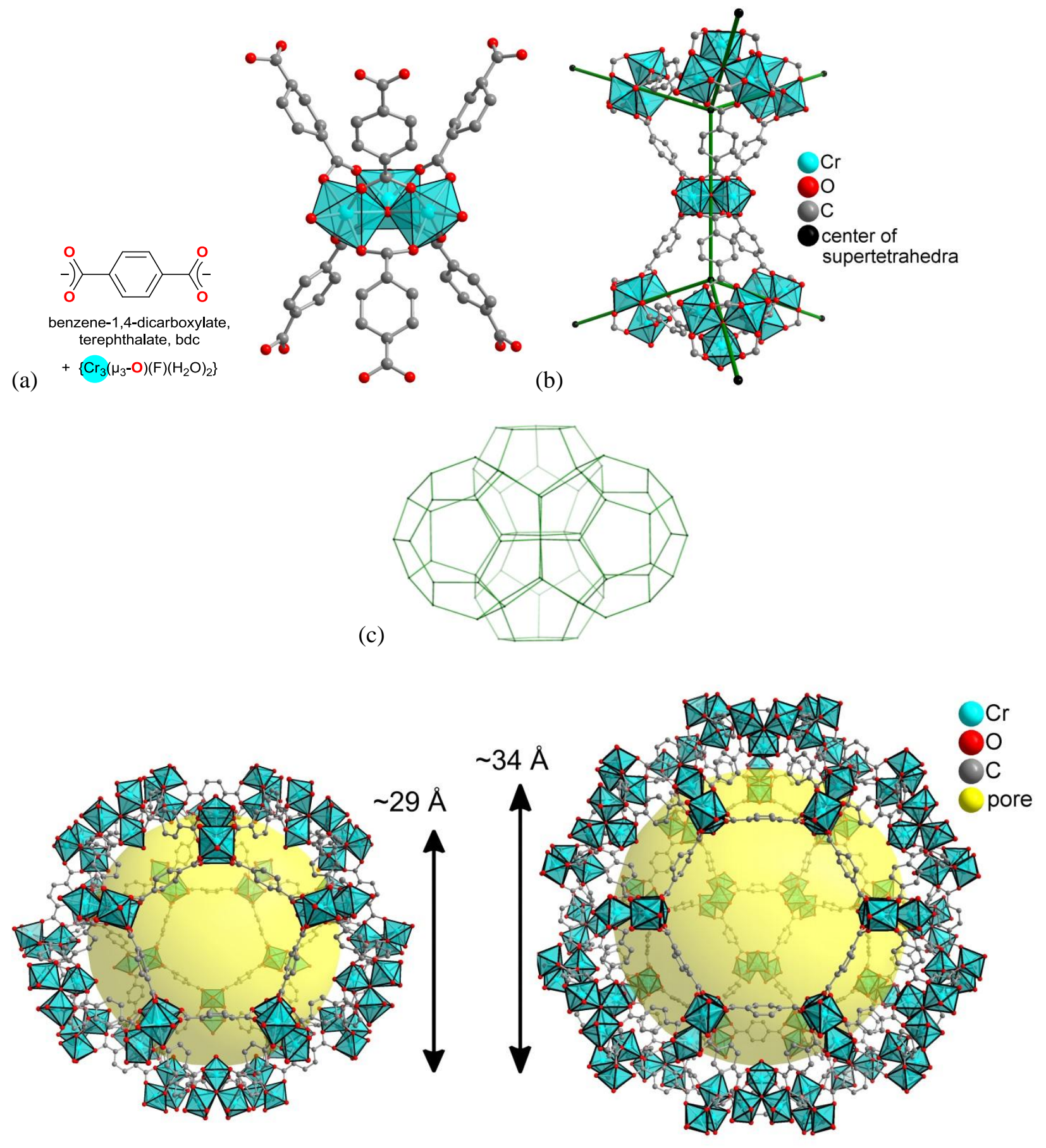

(d)

(e) 

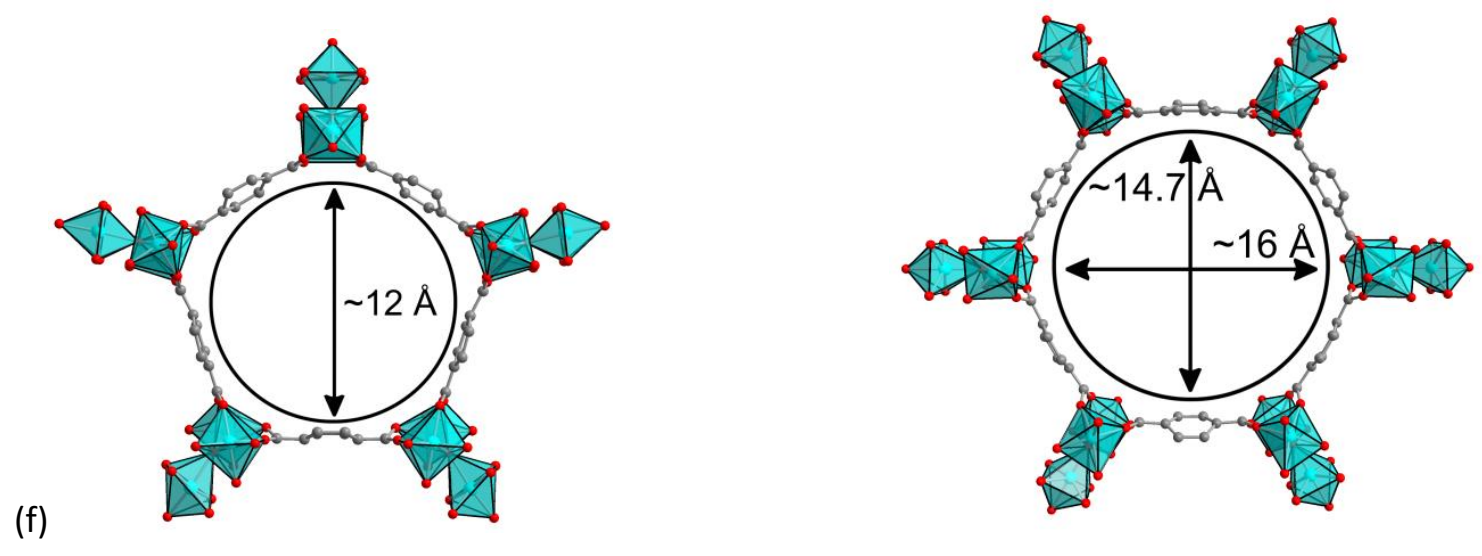

Fig. 1. (a) ligand and metal building blocks in the trinuclear $\left\{\mathrm{Cr}_{3}\left(\mu_{3}-\mathrm{O}\right)\left(\mathrm{O}_{2} \mathrm{C}-\right)_{6}(\mathrm{~F}, \mathrm{OH})\left(\mathrm{H}_{2} \mathrm{O}\right)_{2}\right\}$ building unit; (b) supertetrahedra; (c) mesoporous network; (d) small cage with pentagonal windows; (e) large cage with pentagonal and hexagonal windows; (f) dimensions of pentagonal and hexagonal cage window apertures. Objects in (a) to (f) are not drawn to scale. Graphics have been created from the deposited cif-file for MIL-101Cr (CSD-Refcode OCUNAK). 


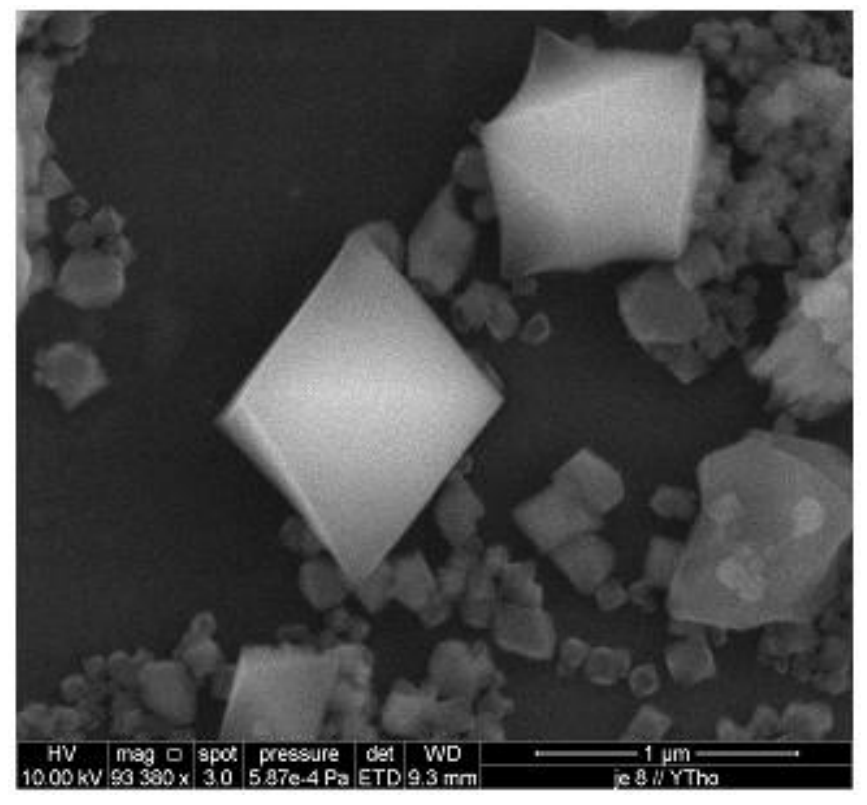

Fig. 2. The SEM picture of MIL-101Cr. 


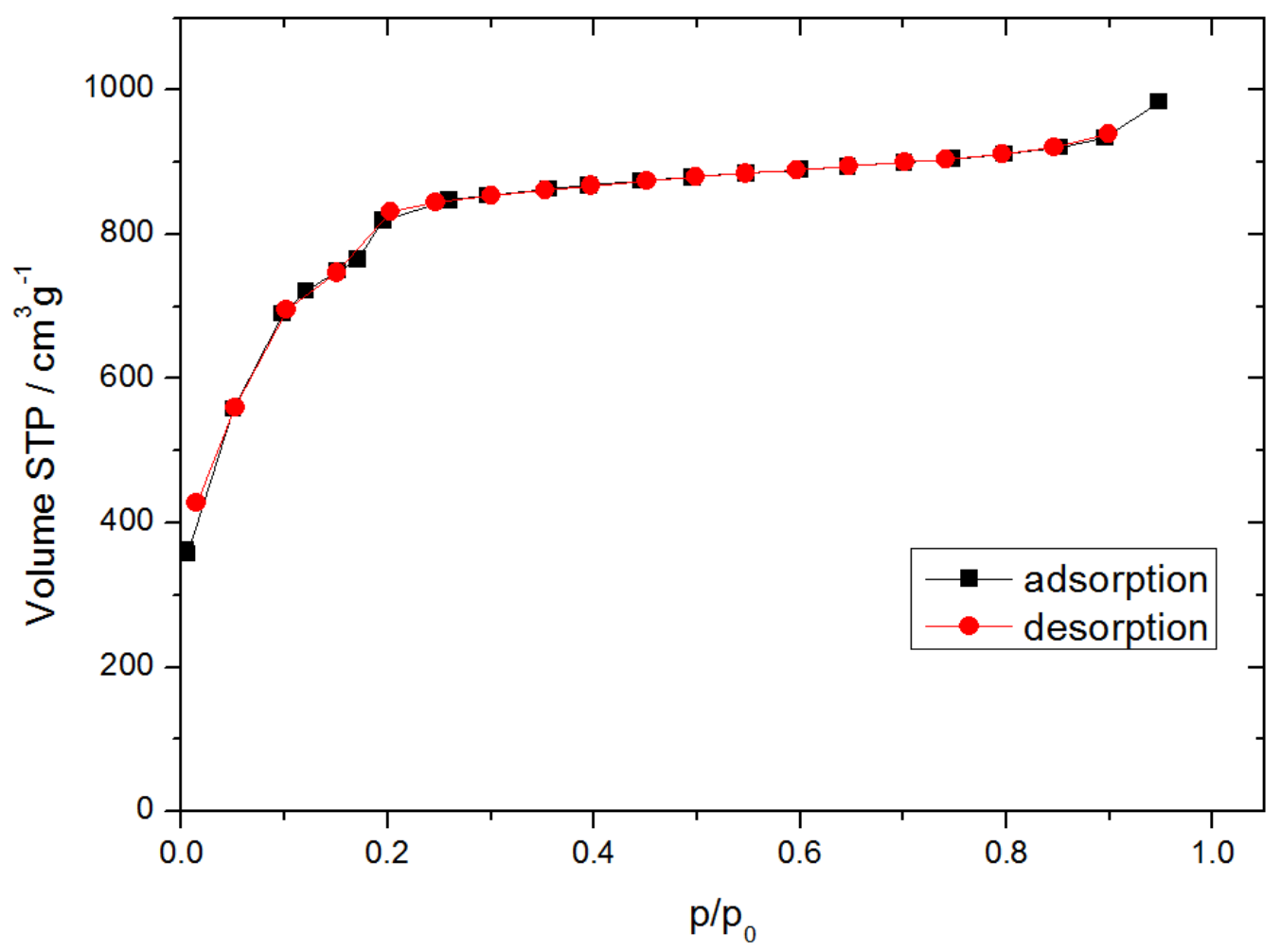

Fig. 3. Nitrogen adsorption and desorption isotherm. 


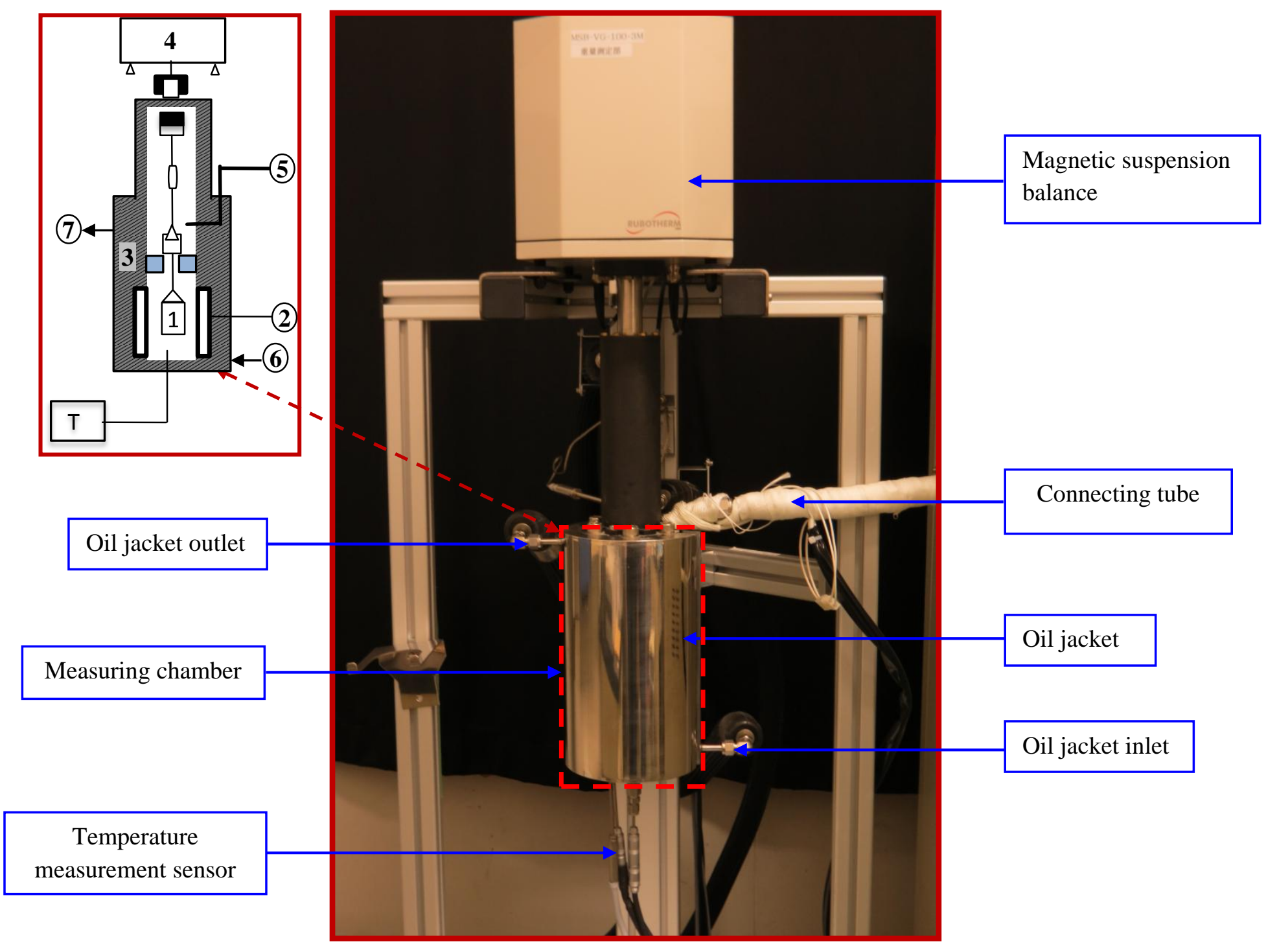

1. Sample cell; 2. Sheathed heater; 3. Circulation oil jacket; 4. Magnetic suspension balance; 5. Connecting tube; 6. Oil jacket inlet; 7. Oil jacket outlet; T:Thermocouple.

Fig. 4. Pictorial view of magnetic suspension balance section. 


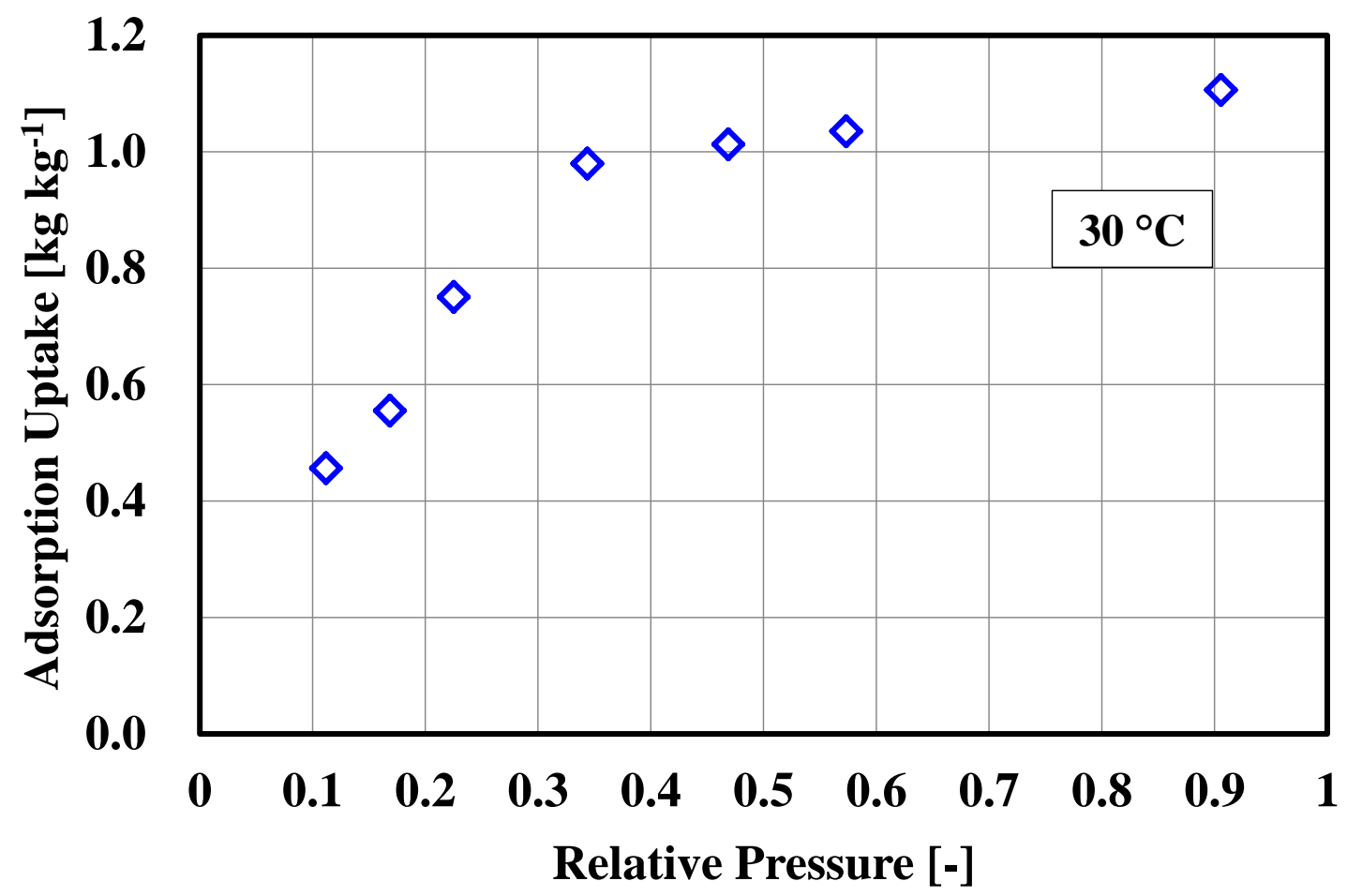

(a)

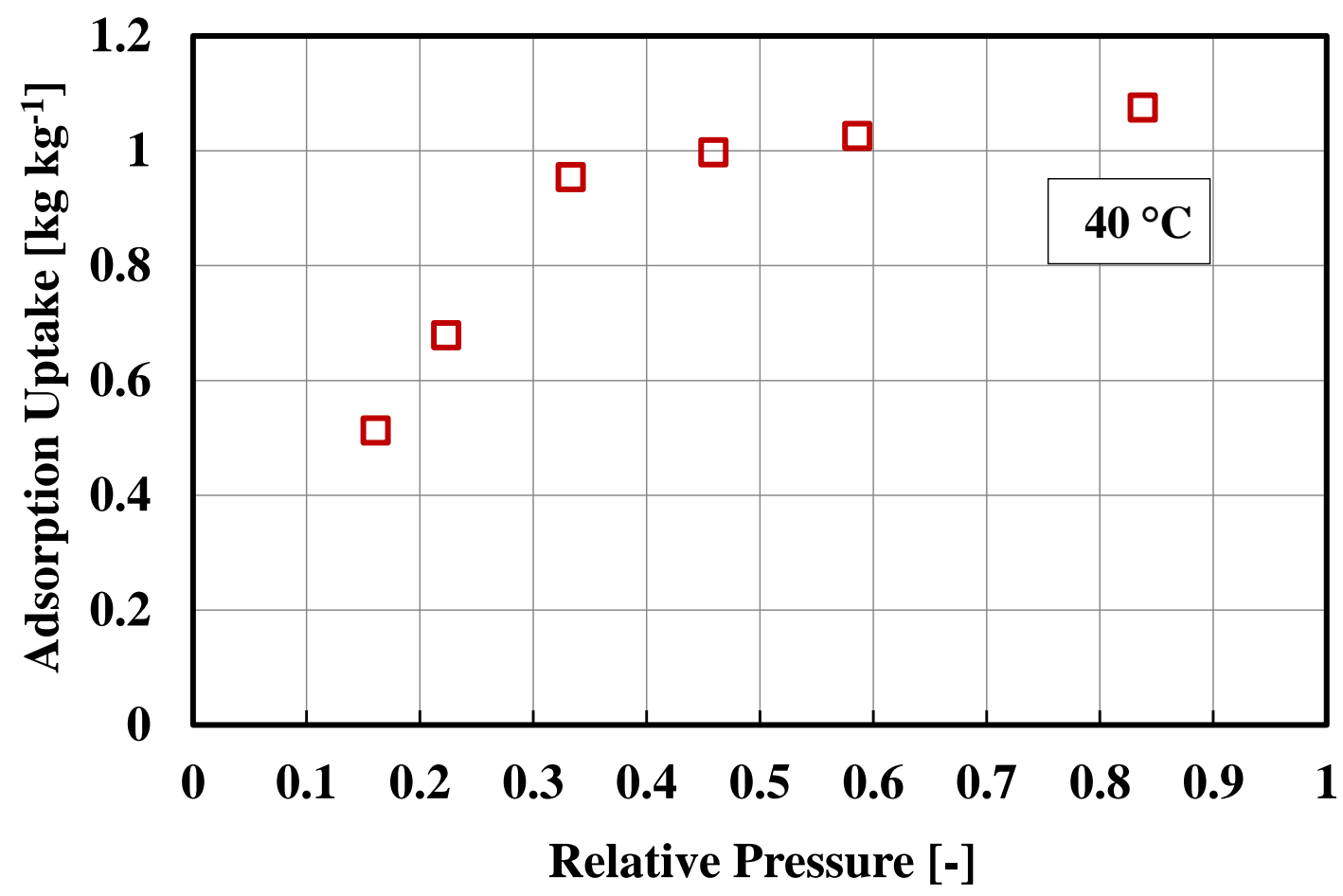

(b) 


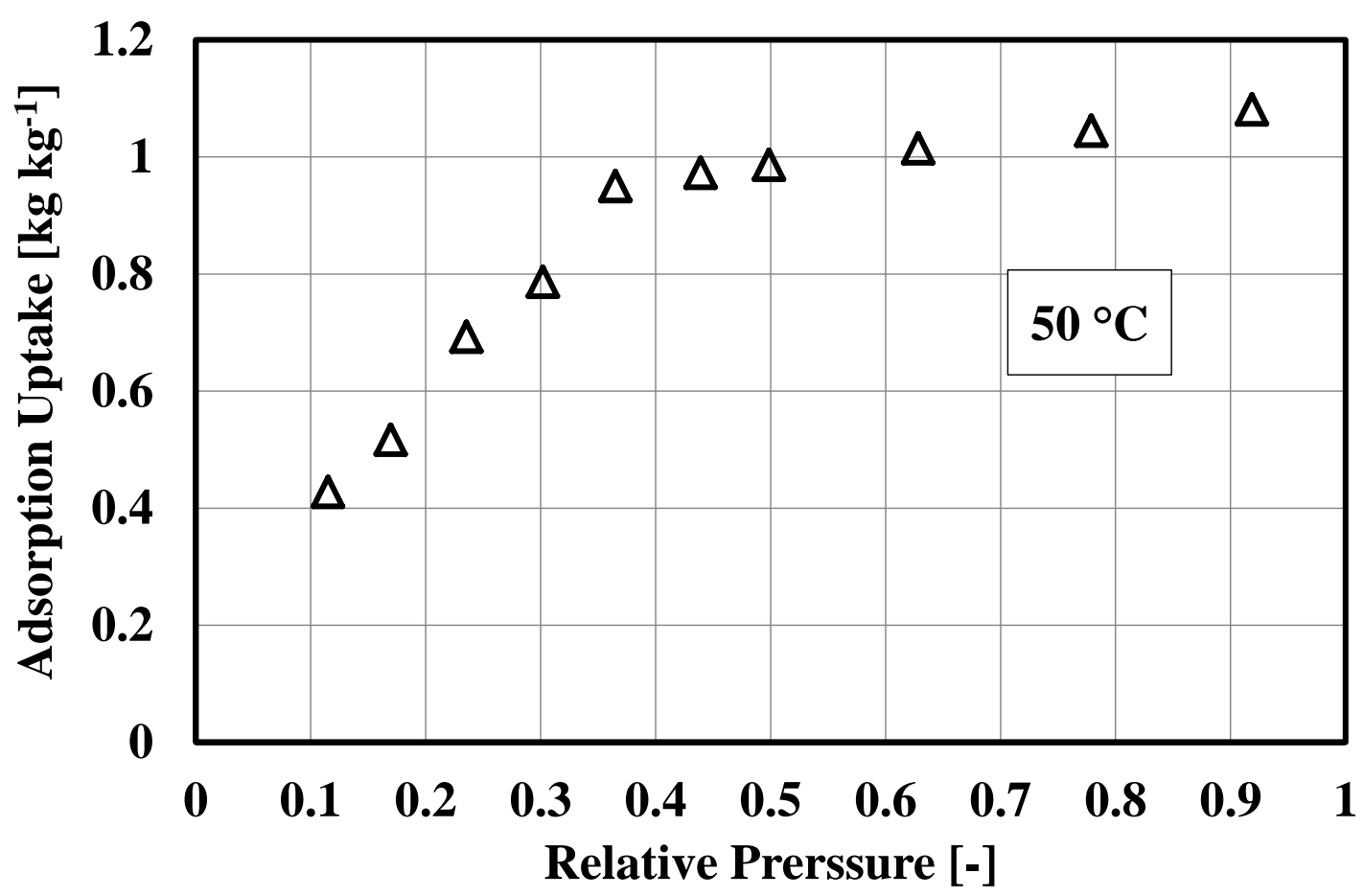

( C )

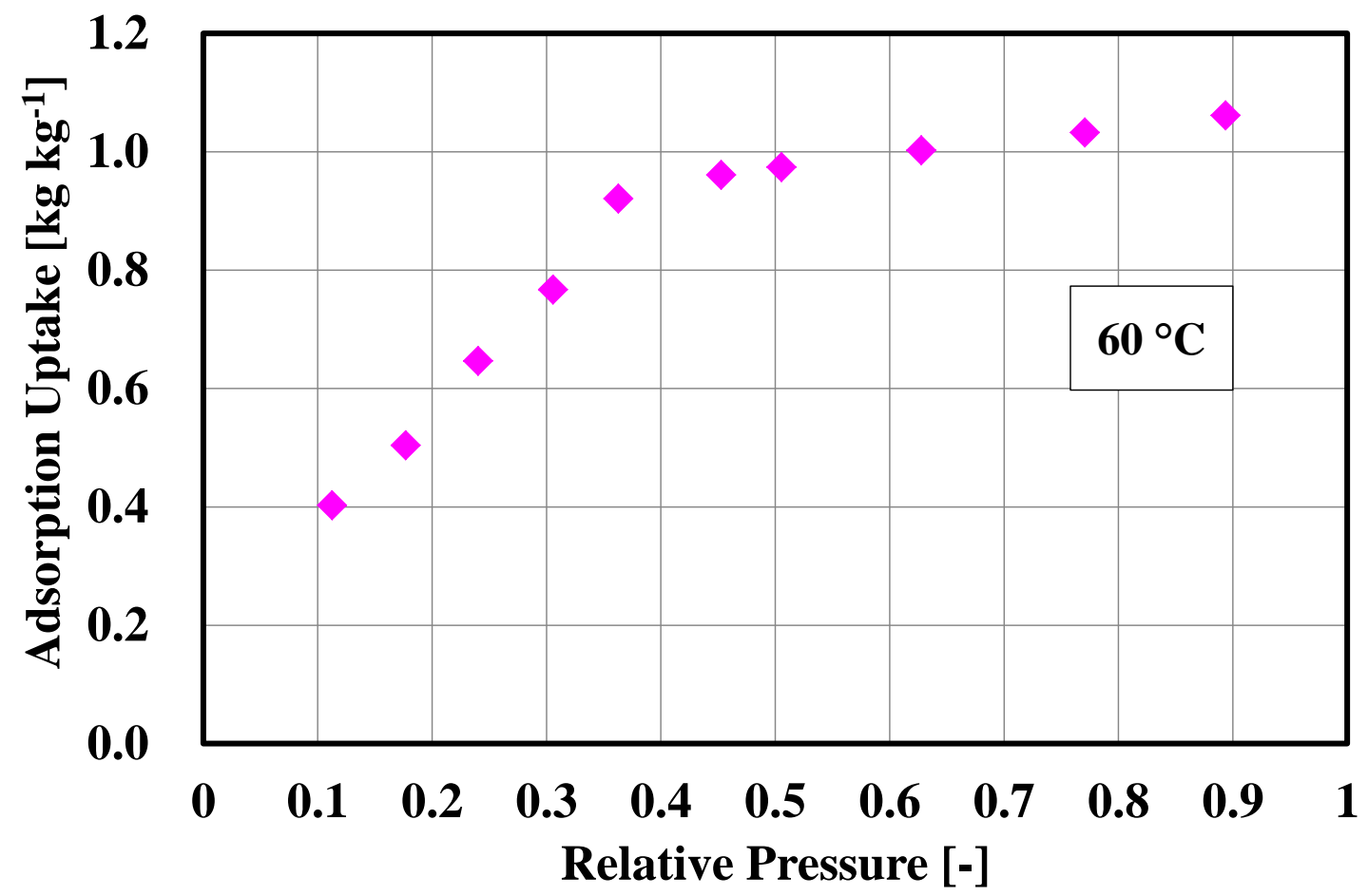

(d) 


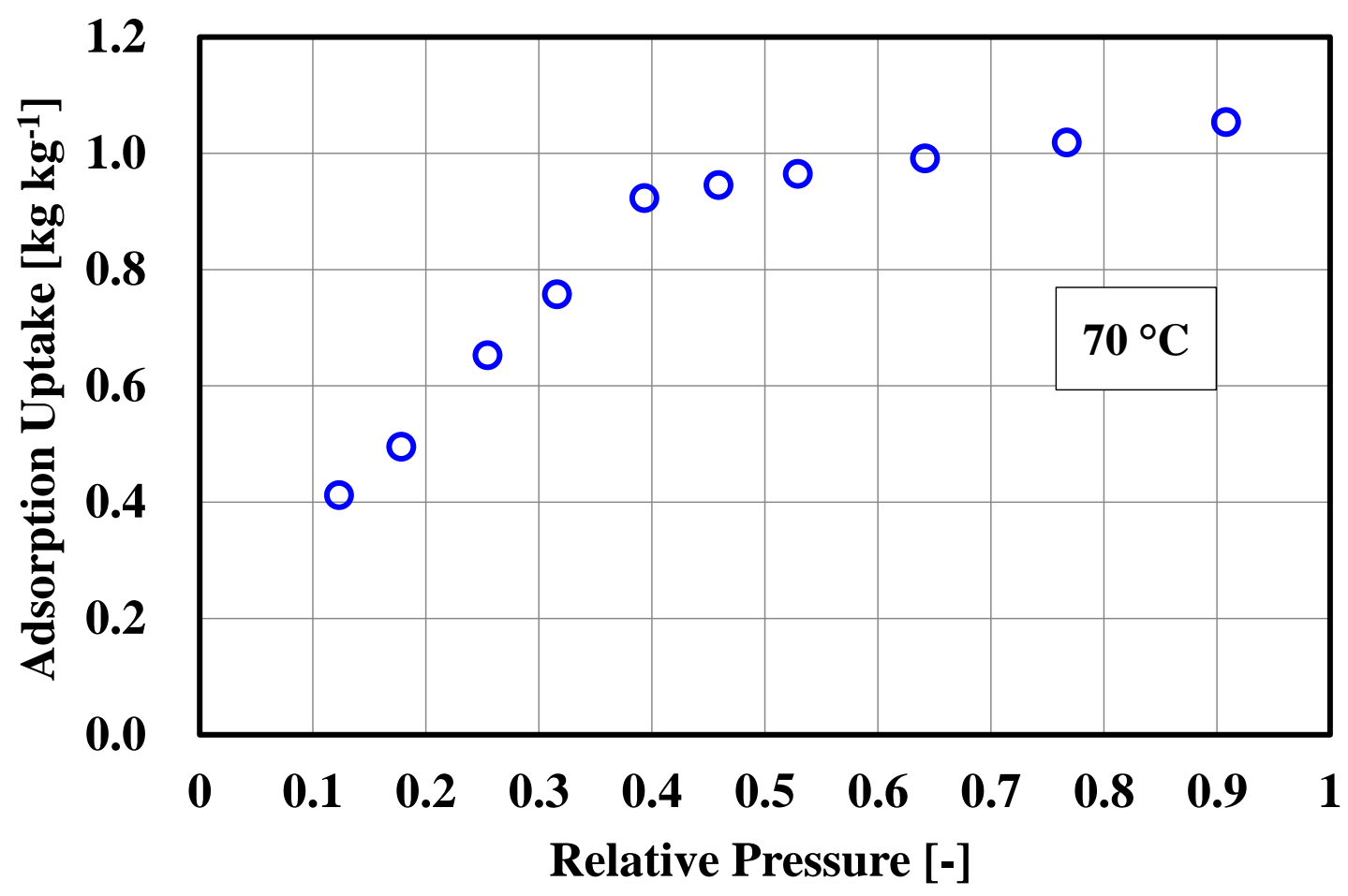

(e)

Fig. 5. Gravimetric adsorption isotherms of MIL-101Cr/ethanol pair. 


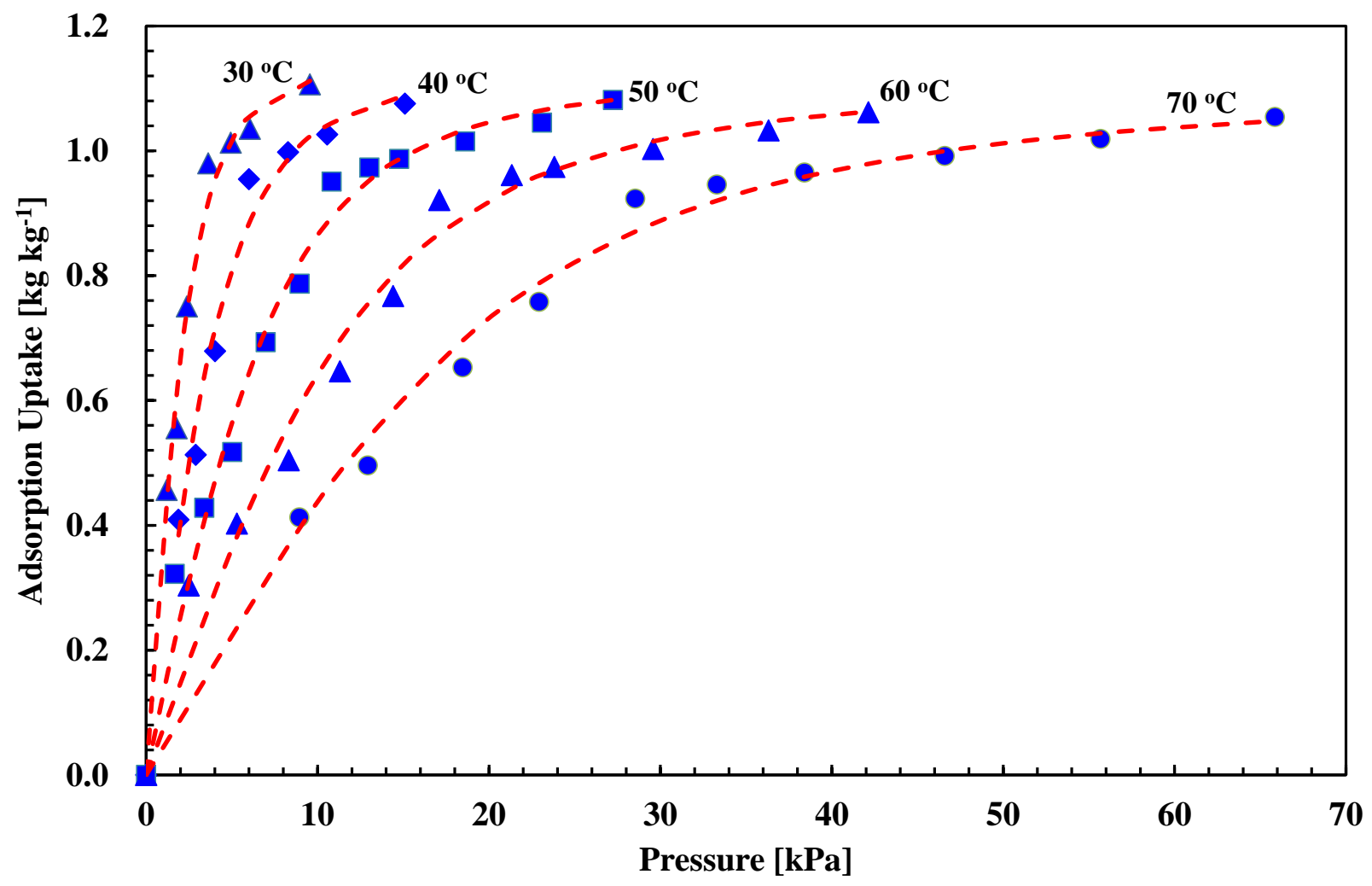

Fig. 6. Adsorption Isotherms using Tóth equation (symbols: experiments; Tóth fitting at individual adsorption temperatures: solid line; Tóth fitting using all temperature range: dashed lines). 


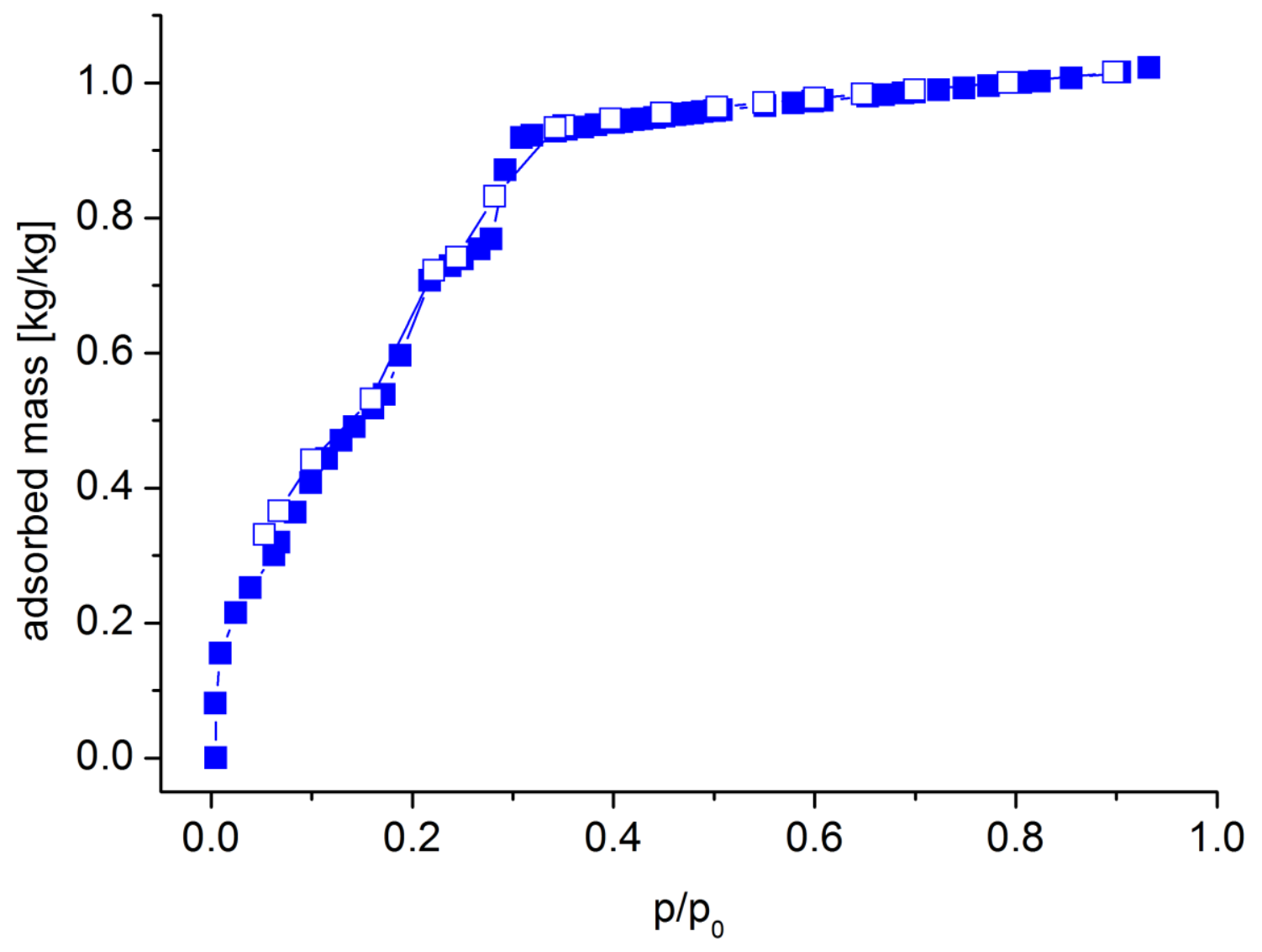

Fig. 7. Volumetric sorption isotherm of MIL-101Cr/ethanol pair at $20^{\circ} \mathrm{C}$. The closed and open symbols refer to adsorption and desorption, respectively. 


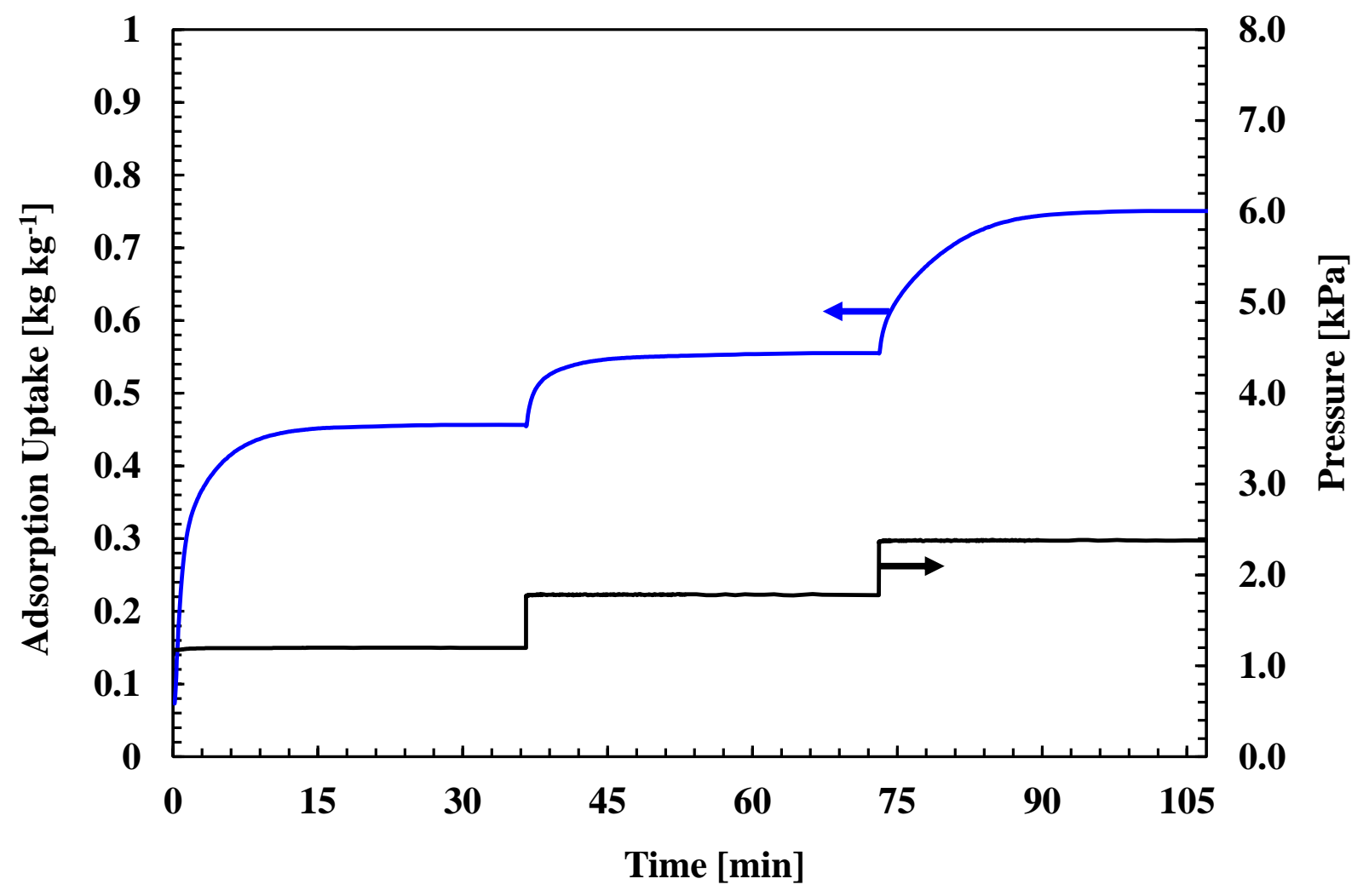

Fig. 8. Plots of adsorption uptake and pressure versus time for MIL-101Cr/ethanol pair at adsorption temperature of $30^{\circ} \mathrm{C}$. 


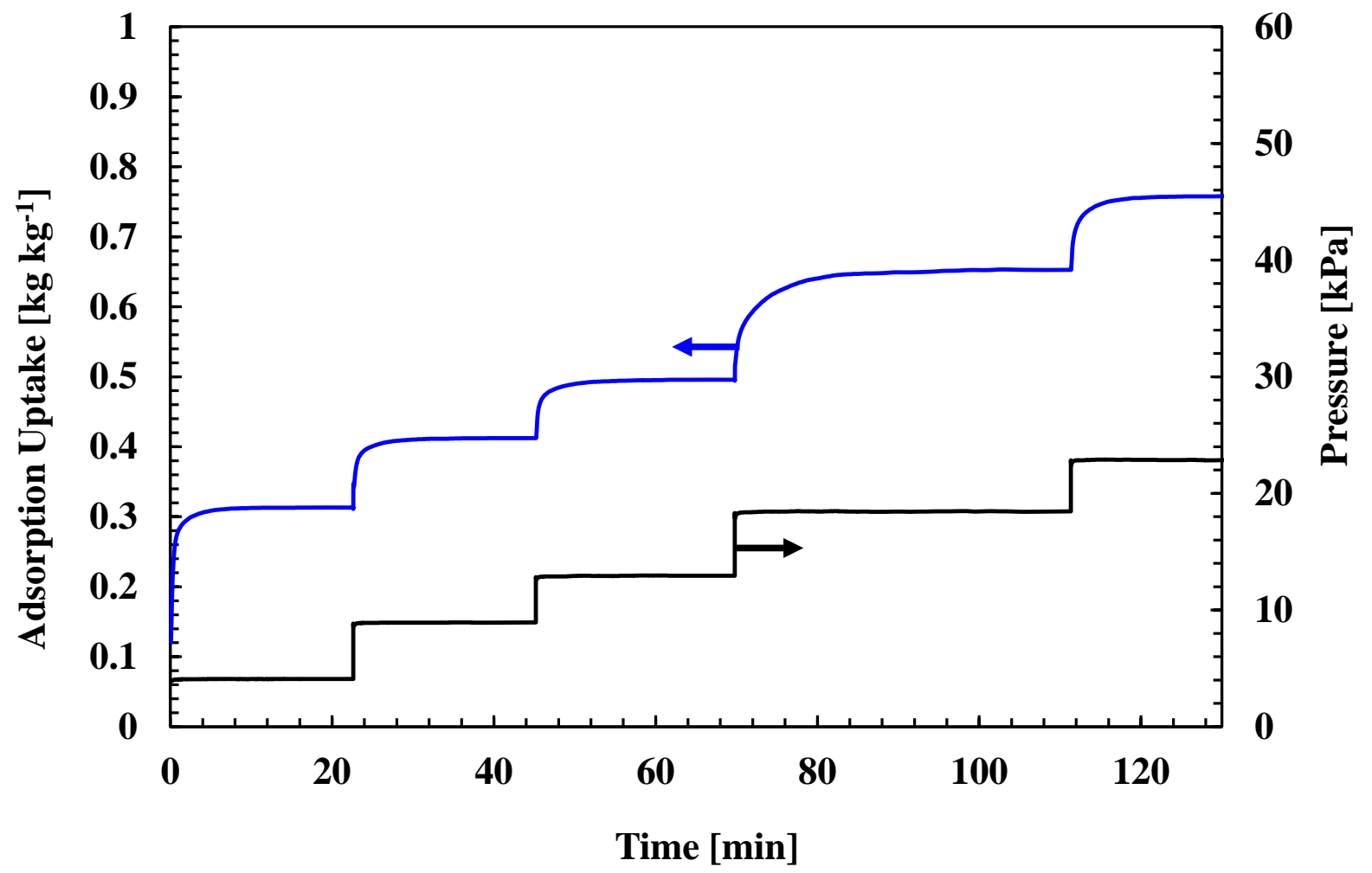

Fig. 9. Plots of adsorption uptake and pressure versus time for MIL-101Cr/ethanol pair at adsorption temperature of $70^{\circ} \mathrm{C}$. 


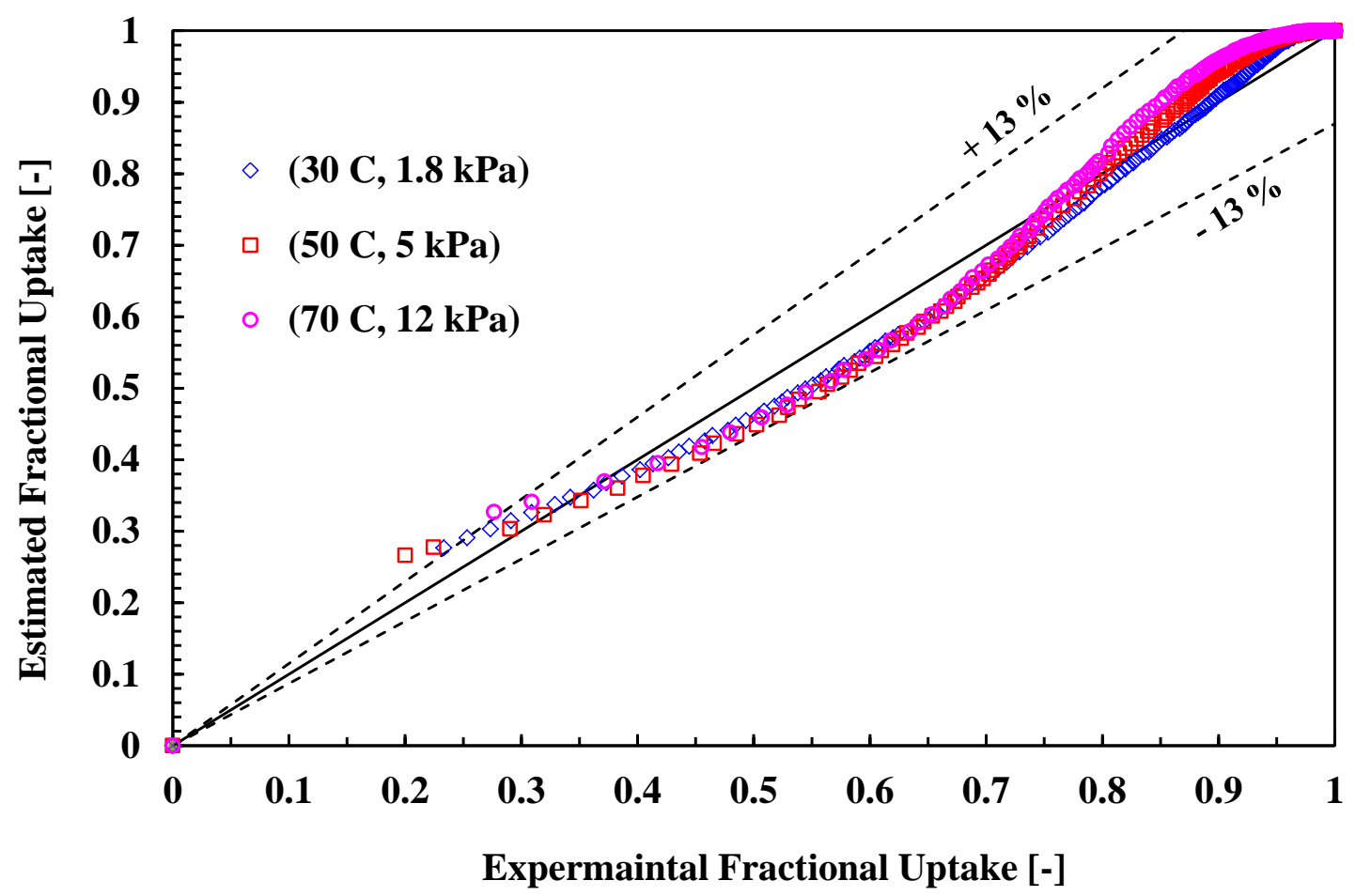

Fig. 10. Plots of adsorption uptake and pressure versus time for MIL-101Cr/ethanol pair at adsorption temperature of $70^{\circ} \mathrm{C}$. 


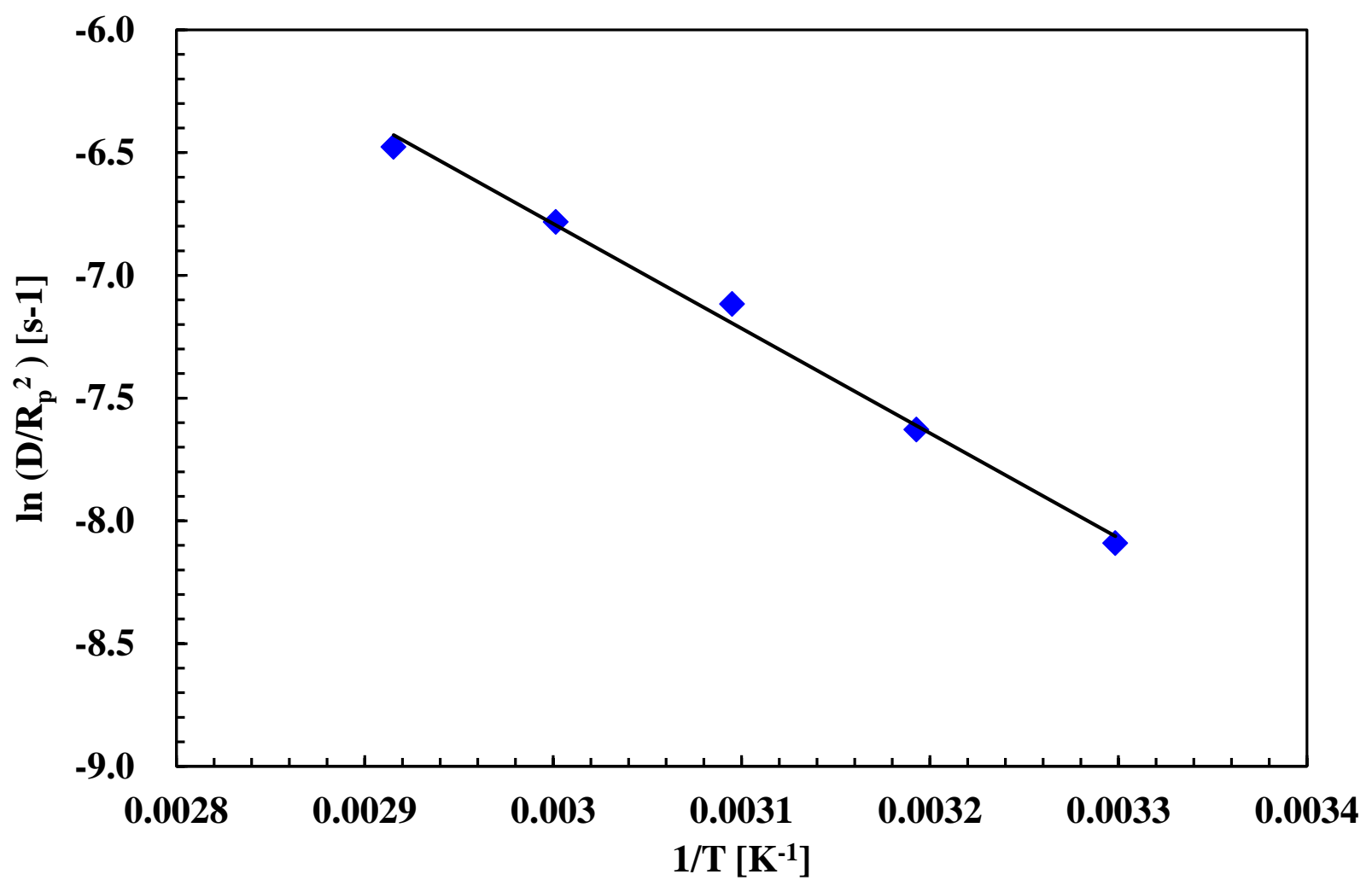

Fig. 11. Arrhenius plot of MIL-101Cr/ethanol pair. 